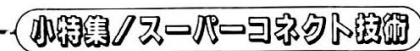

\section{LSI の新境地を開くスーパーコネクト}

\author{
桜 井 貴 康* \\ *東京大学 国際・産学共同研究センターおよび生産技術研究所（†153-8505 東京都目黒区駒場 4-6-1）
}

\section{Super-Connect Technology}

\section{Takayasu SAKURAI*}

${ }^{*}$ Center for Collaborative Research, and Institute of Industrial Science, University of Tokyo (4-6-1, Komaba,

Meguro-ku, Tokyo 153-8505)

Key Words : Supercomnect, Interconnect, System-on-a-Chip, System-in-a-Package, 3-Dimensional Assembly

\section{1.「スーパーコネクト」とは}

最近，スーパーコネクトが注目されている。実装技術者は 激化する国際競争の中「現状を打破する次の一手は何か」と いう観点から，半導体技術者は「システムLSI だけでいい のか」という問題意識からこのスーパーコネクトが議論さ れている。

スーパーコネクトというのは二つの意味合いがある。一つ は「スーパー・インターコネクト」あるいは超配線というよ うな意味合いで, 図 10 ○うに設計ルール $10 \mu \mathrm{m}$ 帯の技術 空白を埋める邽線技術を指すものである1。もう一つは 「スーパーインテグレーション」あるいは超集積というよう な意味合いで, 図 2 のようにベア・チップに近い複数チップ を二次元，あるいは三次元に高密度実装し，電子システムを 作り上げるという新しい実装技術体系である。したがって， スーパーコネクトというのは超接続とも訳されるべきもので ダブル・ミーニングを持っている。

スーパーコネクトが提唱された一年半前は単に技術分野だ けがぼんやりと特定されており，具体的な方向性や実現可能 性については見えていなかった。しかし，このところ一つの

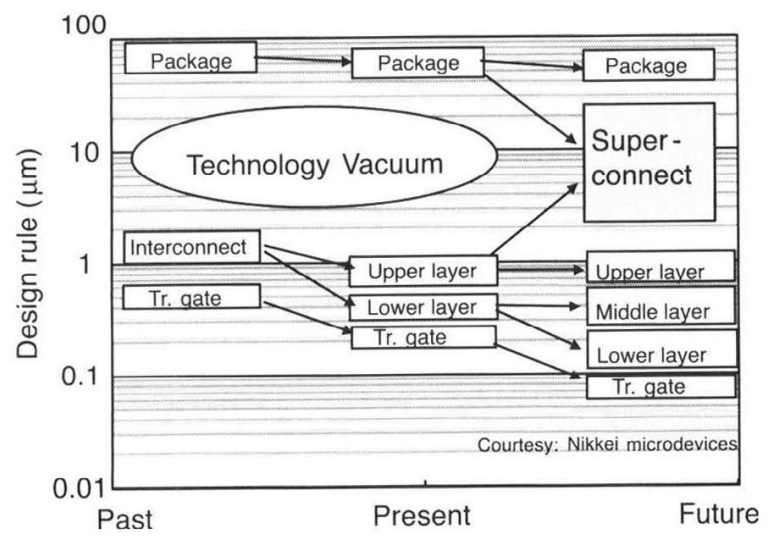

図 $110 \mu \mathrm{m}$ 带の配線という技術の空白地带を埋めるスーパーコ ネクト技術
方向性としてシステム・イン・パッケージや, 薄くしたチッ プを積層するスタックト・チップが具体性をもって浮上して きた。スタックト・チップ間の接続にはSi 基板中の埋め込 みビアを使う方式やインターポーザを使う方式，チップの上， あるいは横に追加で配線を作りこむ方式 2 などが提案されて いる。 $10 \mu \mathrm{m}$ 帯の技術はまだ使っていないが, 簡単なシステ ム・イン・パッケージはスタックト・チップをボンディング するアプローチで，すでに数社が製品を出している。

\section{2. システム LSI と課題}

一方，半導体側の問題意識を見てみよう。ここ $3 ， 4$ 年, 半導体各社はメモリ中心のビジネスから, 付加価值が高いシ ステムLSI 重視の方向へ舵を取ってきた。システム LSI と は複雑なシステム機能を 1 つのシリコンチップに作りこんだ ものである。ゲームやデジタルテレビ向けなど巨大マーケッ トに向けて, 大容量のダイナミックメモリとプロセッサをワ ンチップ上に一緒に集積したシステム LSI まで開発されて いる。たとえば，2チップ構成だとメモリとプロセッサ間の データのやり取りに多大な電力がかかっているものが, シス テム LSI 化することで消費電力を $1 / 4$ にまで低減できた例 などもある。このようにシステム LSI では, 今まで多数の

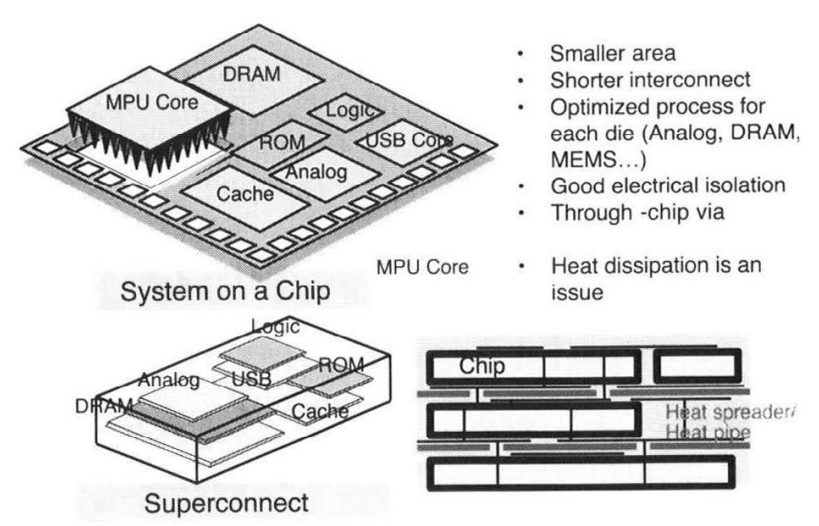

図 2 システムLSI とスーパーコネクト 
チップで作られていた電子システムをワンチップ化すること により数倍高性能にしたり，低電力化したりできる。

しかし，システムLSIを実際に作ってみると，いくつか の)問題点も明らかになってきた。システムLSI の設計には, すでに設計検恠の終った IP と呼ばれる大きな同路ブロック の設計データを組み合わせて作り上げる方式がとられる。数 千厅個に上るトランジスタを使ったシステムを一から設計し ていては，とても開発期限に間に合わない。そのため，シス テム LSI の成否には多数のIP が市場に流通していることが 重要であり，そのような流通市場もいくつか誕生した。

ここで次のような場合を考えよう。性能や機能の観点から， どうしても $\mathrm{A}$ 社製のプロセッサと $\mathrm{B}$ 社製のメモリをワン チップ化しシステムLSI 化したいとする。これらの回路ブ ロックがIPとして流通していれば， A 社と B 社からこれら の回路ブロックの設計データを調達し，どこかの半導体製造 会社に持ち込んでシステムLSIを作ることができる。とこ ろが，A 社がどうしてもプロセッサの設計データを一般の 市場には出さないとしよう。理由としては自社で製造も行う ことによって高付加価值の製品に仕上げたいといったことが 考えられる。すると $\mathrm{A}$ 社と $\mathrm{B}$ 社の製品を使ったシステム LSI を作ることができなくなってしまう。今までは，A 社と $\mathrm{B}$ 社から独立にチップを購入して，プリント基板を使って高 性能な電子システムが組めたものが，システム LSI ではA 社と $\mathrm{B}$ 社の組み合わせは不叮能となる。これでは所望の電 子システムができない。

また，本質的にワンチップ化できないものもシステムLSI 化の障害となる。たとえば，ガリウム七素という半導体基板 を使った高速なチップとシリコン基板のチップをワンチップ 化するのは不可能だ。高性能なアナログチップとデジタル チップをワンチップ化するのにも無理がある。デジタル回路 から出されるノイズが基板を伝わってアナログ部分に悪影響 を及ぼし，性能を低下させてしまうためである。特定プロセ スに特化したメモリなども他の IP とのワンチップ化はむず かしい。その他，システムLSIの開発や検証には，年単位 の期問がかかったり，億円単位のコストがかかったりすると いった問題もある。システム LSI ではチップサイズが大き くなって歩留まりが低下し, 価格が跳ね上がるといった指摘 もされている。

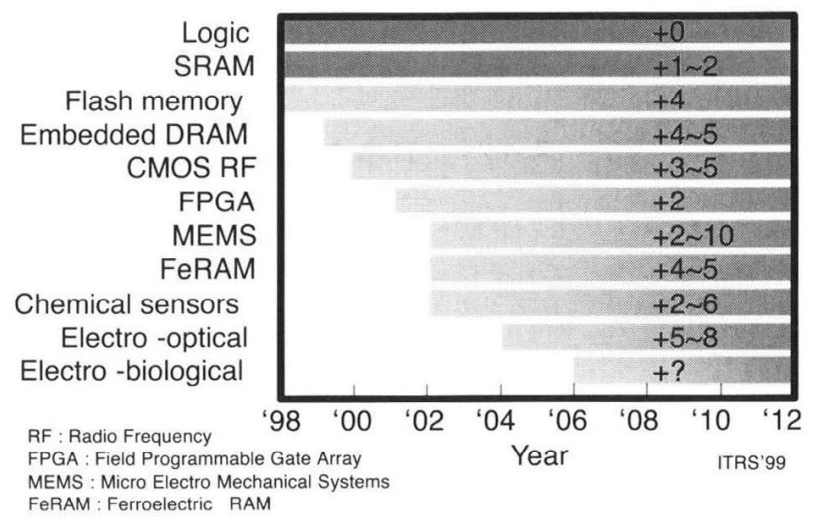

図 3

各種技術を混載させるために必要なマスク数の増加
システムLSI の各種の問題の中でも一番の問題と思われ ているのが，異種の技術の混載であろう。図 3 に示す上うに， DRAM やマイクロマシン混載, 各種の化学センサーの混載, しいてはバイオ機能混載などでは, 多くのマスクが必要とな り, 非常に高い開発コストがかかる。DRAMを混載した ディープサブミクロン・チップのマスクセットは数千万円の オーダであり, 通常の少量多品種プロジェクトが使えるもの ではない。万人が使えるLSI 技術はどこに行ってしまった のだろうか。FPGA と見る向きもあるが，セルベース・ア プローチに比べて 40 倍の面積や電力オーバーヘッドを考え ると, すべての電子システムが FPGAになるというのは考 えにくい。

混載のコストだけでなく，混載プロセスの開発もネックに なる。たとえ，どこかの会社がすべての混載を許すプロセス 技術をある世代で実現したとしても，1年単位で進化する設 計ルールに合わせてすべての混載プロセスを開発しなおす工 ンジニアリング・リソースはアサインしきれないだろう。ま た，混載技術はそれぞれで最適化した技術に比べれば，性能 が下がる。

\section{3. 各種のスーパーコネクト}

システム LSI がすべての電子システム構築の解ではなさ そうだとしても，今さらプリント基板に多数0チップを載せ て電子システムを組むというのでは性能的に限界がある。図 4 のようにオンチップ接続とオフチップ接続では性能などに $2 ， 3$ 析のギャップがあるためだ。このような問題を軽減す るものとして，前述のシステム・イン・パッケージという新 しい三次元実装技術が注目されてきている。システム・イ ン・パッケージとは，たとえば，チップをインターポーザと 呼ばれる超薄型で小型な支持物に固定し, これらを複数個組 み合わせて，システムを一つのパッケージの中に入れてしま おうというものである。半導体チップ以外にもコイルやコン デンサ，水晶発振子などもワンパッケージに収められる新し い三次元実装形態だ。こうすることによって速度, 電力, 実 装面積などを従来のプリント基板で作った電子システムより 数倍改善することができ，システム LSIにも敵する性能 を実現できる場合も多い。このような新しい実装技術では スーパーコネクト，すなわち $10 \mu \mathrm{m}$ 帯の配線技術が活躍す る(図 1 参照)。

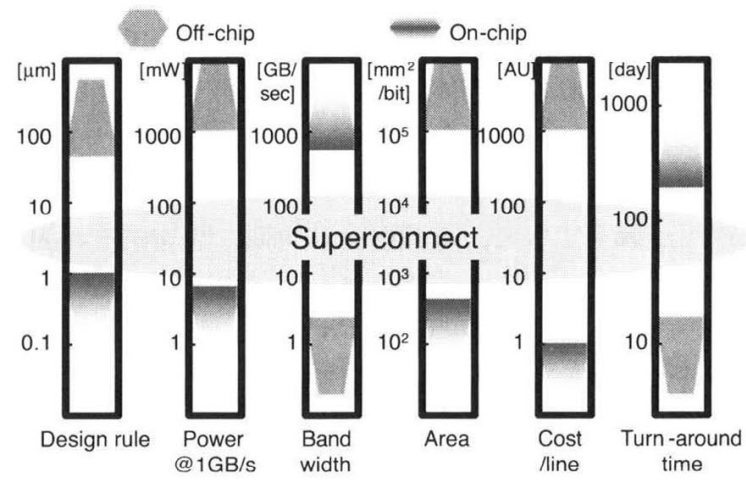

図 4 オンチップ接続とオフチップ接続での性能格差 


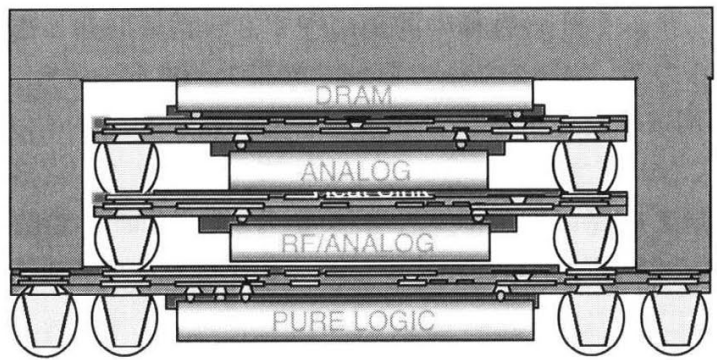

図 5 インターポーザを使ったスーパーコネクトの例

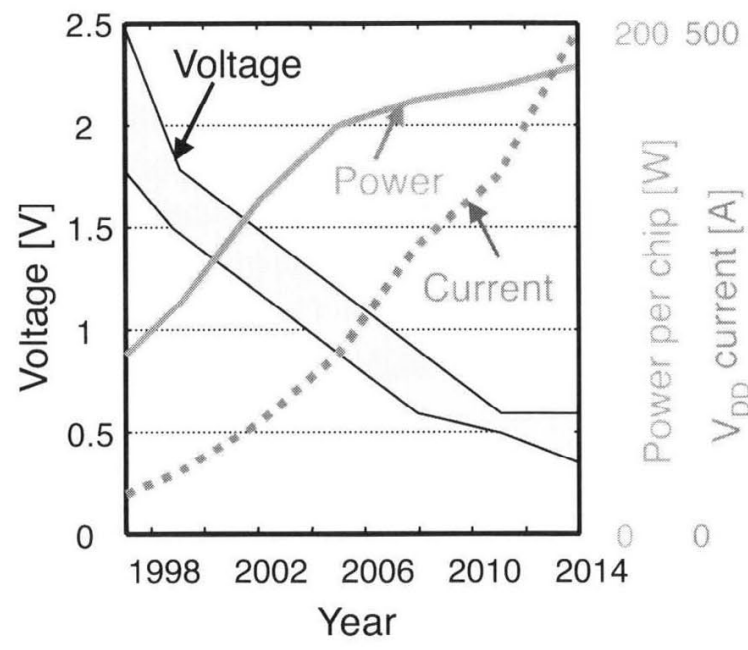

図 6 LSI の電源電压, 電力および電源線の電流

昨年 2 月にサンフランシスコで行われた世界最大の LSI の学会である ISSCC(国際固体回路学会)で, 新しい実装の 流れに注目が集まった。東北大学のグループ3) や米国大学 ${ }^{4)}$, 米国企業 ${ }^{5)}$ からの発表が相次いだ。特に, 日本のベンチャー からは図 5 のようにスーパーコネクトの技術が現実のもので あることを示してひと際の注目を集めた。信頼性のデータや 低コスト性まで示された6)。

また，今年 2 月に行われた ISSCC ではシステムLSI の電 源電圧を検討するパネル討論では，アナログ技術者やメモリ 技術者から，システム・イン・パッケージへの期待が示され た。特に，メモリー・オフ・チップという新語も飛び出し, システムLSI 万能ではないことが改めて確認された。

\section{4 、 スーパーコネクトが解決する LSI の問題}

スーパーコネクトは Giga-Scale Integration(GSI)のいく つかの問題も解決すると期待されている。GSI では消費電力 が増加する。これは半導体産業の指導原理である比例縮小則 の当然の㷌結であり不可避である。また，微細デバイスを使 うために GSI では電源電圧は低下する。消費電力が増加し, 電源電圧が低下すると，電源電流は極端に増加する。図 60 ように，数十アンペアから数百アンペアをチップに供給しな くてはならない時代はそこまで来ている。このような大電流 世代では電源線の抵抗による電圧降下，すなわち IR ドロッ プの問題が顕在化する。この問題の解決には $10 \mu \mathrm{m}$ 以上の 厚い金属層が必要となる(図 7 参照)。スーパーコネクトが活 躍するゆえんである。この他にもスーパーコネクトはGSI

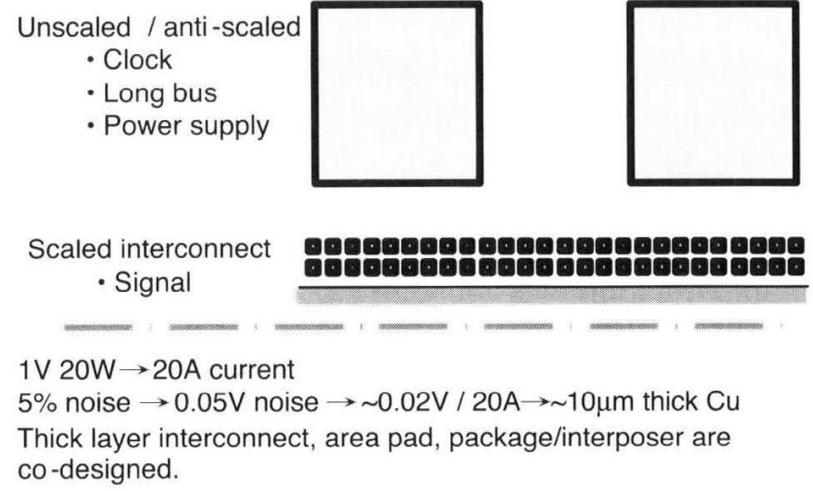

Unscaled / anti-scaled

- Clock

- Long bus

- Power supply

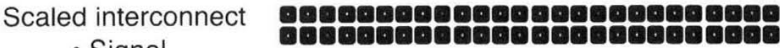 - Signal

$1 \mathrm{~V} 20 \mathrm{~W} \rightarrow 20 \mathrm{~A}$ current

$5 \%$ noise $\rightarrow 0.05 \mathrm{~V}$ noise $\rightarrow \sim 0.02 \mathrm{~V} / 20 \mathrm{~A} \rightarrow \sim 10 \mu \mathrm{m}$ thick $\mathrm{Cu}$ Thick layer interconnect, area pad, package/interposer are co-designed.

図 7 大電流, あるいは配線遅延低減のために厚膜配線が必要と なる

の配線遅延の低減にも効果を発揮すると考えられる。

現在まで，配線遅延の低減にはインバー夕を配線に等間隔 に挿入する，いわゆる，リピータ・インサーションという技 術と，抵抗の少ない断面積の大きい配線を使用する方法が知 られていた。しかし，リピータ・インサーションは消費電力 を増加させる。リピータの数が多くなってきた現状では，低 消費電力化のために，断面積の大きい配線を使用する方法も 魅力的になってきている。これが，スーパーコネクトによる 信号遅延の低減化である。まずは，クロック配線などでの利 用が考えられる。

このような $10 \mu \mathrm{m}$ 帯の配線技術は，パッケージ女るいは 実装側の技術になるのか，シリコン LSI プロセスの延長線 上の技術になるのかは，まだ結論が得られていない。しかし， 現状では実装側からの方がより早く実現しそうである。10 $\mu \mathrm{m}$ 帯のマイクロバンプによるチップ間接続などには実用例 が出てきている。 $\mathrm{Si}$ 基板中に縦に埋め込む $10 \mu \mathrm{m}$ 帯のス ルービア技術という，高性能 3 次元スタックト・チップを実 現する基本技術も，完成度を上げてきた。その他，バイオ機 能混載といった新規のアプリケーションに向けても，スー パーコネクトが検討されている。

システムLSI0流れは，もちろん滔滔としたものであろ う。しかし，システムLSIだけですべての電子システムを カバーできるわけではない。スーパーコネクトを利用したシ ステム・イン・パッケージも電子システム構築に欠かせない ものになるだろう。ここでITRS という半導体関連の国際 ロードマップに記された一つの言葉が思い起こされる。すな わち，「これからの電子システムの差別化をするのに，実装 やパッケージの重きが増加している」7)。

\section{5. スーパーコネクトの課題}

スーパーコネクトの課題についても触れて抢こう。一時代 前, マルチ・チップ・モジュールなるものが騒がれた。多少 使われはしたが，結局，はばたくまでにはいたらなかった。 マルチ・チップ・モジュールが離陸しなかった一つの大きな 原因はKnown Good Die (KGD)の問題である。複数のべ ア・チップを組み合わせてシステムを構築するためには, 正 しく動作することが確認されたチップ(KGD)を組み合わせ る必要がある。しかし，チップにプローブを当てるだけでは 
なかなか使用するスピードでの高速テストができなかった。 したがって，KGDを選別し確保することができなかった。 この辺の事情とコスト高がマルチ・チップ・モジュールのつ まずきの原因だった。この辺に関して，システム・イン・ パッケージは大丈夫なのか。前述したインターポーザを使っ たアプローチでは，KGD の問題が解決できることが示され ている。また，低コスト性にもメドがついたようだ。

もう一つの大きな課題は，ベアチップの流通である。技術 的にいえば，すでにメモリーなどでは実績がある。したがつ て，この問題は主にビジネスマターであり，スーパーコネク ト技術が電子システム構築に必須になってくれば，自然と解 消するものと考えられる。

システム・イン・パッケージの課題は他にもある。作る立 場から言えば, $10 \mu \mathrm{m}$ 帯のスーパーコネクトを低コストで高 信頼に作る技術を確固たるものにする必要がある。また，設 計の立場からすると，システム・イン・パッケージの設計 ツールの確立が望まれる。三次元的に実装する場合は放熱の 問題もクリアする必要があるだろう。夢を言えば, チップと インターポーザを $10 \mu \mathrm{m}$ ピッチで接続できれば，全く新し い世界を開くことも可能である。また，このような接続部分 が着脱可能になれば，ほとんど革命と言っても良いだろう。 このような技術は, 電子システムの作り方と性能，コストを 大きく変える起爆剤になる可能性を秘めている。

\section{6. スーパーコネクトは電子産業の牽引役}

日本は半導体技術も実装技術も技術としては世界最先端を 走っている。しかし，米国で設計しアジア諸国で製造すると いった水平分業型のビジネスモデルに対してのコスト競争力 の低下から，ここ数年ビジネスとして米国などに水をあけら れる結果となってしまった。日本の有する各種の技術分野を 有機的に連携させ，異業種連携的な色彩も加えながら半導体 産業を再生することが，わが国の電子産業の将来の競争力を より確固たるものにすると考えられる。システム・イン・
パッケージの設計は半導体チップの設計と密接な連携を取る 必要があり，したがって，分野間の有機的な連携なくしては 高性能な最終製品に仕上がらないためである。つまり，半導 体側と実装側のコデザイン(協調設計)が必須であり，同一地 域で密接に連携をとる必然性が出てきている。

連携プレーにたけた各社がシステム・イン・パッケージを 切り札に半導体と実装で共存共栄を図る。その意味でス一 パーコネクトは日本電子産業復活の救世主になりえる。その ために，現在最も欠けているのは，システム，半導体，実装 の各技術者がビジョンを共有して真摰に技術交換できる 「場」が必要になってきている。

(2002-3-5 受理)

\section{文献}

1) M. Kimura ; "Superconnect: 21 st Century LSI Production and Design Method" Nikkei Microdevices, No. 180, pp. 62-79, June 2000 .

2 ) H. Goldstein ; "Packages Go Vertical” IEEE Spectrum, pp. 46-51, Aug. 2001.

3 ) M. Koyanagi et al. ; "Neuromorphic Vision Chip Fabricated Using Three-Dimensional Integration Technology” ISSCC Digest of Tech. Papers, pp. 270-271, Feb. 2001.

4 ) A. Naeemi, C. S. Patel, M. S. Bakir, Z. Ha, K. P. Martin, and J. D. Meindl ; "Sea of Leads : A Disruptive Paradigm for a System-on-a-Chip (SoC)" ISSCC Digest of Tech. Papers, pp. 280-281, Feb. 2001.

5 ) J. Burns, et al. ; "Three-dimensional Integrated Circuits for Low-Power, High-Bandwidth Systems on a Chip" ISSCC Digest of Tech. Papers, pp. 268-269, Feb. 2001.

6 ) K. Ohsawa, H. Odaira, M. Ohsawa, S. Hirade, T. Iijima, S. G. Pierce ; "3-D Assembly Interposer Technology for NextGeneration Integrated Systems" ISSCC Digest of Tech. Papers, pp. 272-273, Feb. 2001.

7 ) International Technology Roadmap for Semiconductors, ITRS'99 p. 213. 